\title{
CAPÍTULO II - APRESENTAÇÃO DE JOSÉ DO NASCIMENTO MORAES, O INVENCÍVEL DEGENERADO
}

A análise da obra (corpus deste trabalho) e a comprovação de nossa tese geraram a necessidade de conhecer vida e obra do homem José do Nascimento Moraes para o reconhecimento das condições sócio-históricas de produção e para a aplicação da metodologia da $\mathrm{AD}$.

Nossa pesquisa nos levou ao universo íntimo do escritor. Conhecemos sua família, caminhamos pelas ruas de São Luís, que são retratadas por ele em suas obras, descobrimos sua africanidade literária e seu estilo. Desvendamos aspectos sociais, políticos e culturais que fazem parte de seus escritos, dos quais ecoam um "dizer" da resistência negra que não somente condiz com nossa hipótese de trabalho, mas também denotam a presença de um intelectual à frente do seu tempo, cujo discurso está intimamente marcado pela negritude.

Ao adentrar seu universo, de algum modo, constrói-se um percurso diferenciado em direção a um discurso paratópico que se dá por meio de um enunciador-anunciado, o qual se mantém e se sustenta como testemunho e documento paratopicamente, conforme comprovaremos em nossa análise final ${ }^{29}$. Este capítulo faz-se necessário porque é importante (re)conhecer as condições sócio-histórico-culturais em que foi produzido seu discurso e depreendermos os efeitos da paratopia na organização e funcionamento do discurso que selecionamos para esta pesquisa.

Conhecer Nascimento Moraes é mister para (re)conhecer as condições sócio-históricas de produção e analisar o discurso da negritude presente na enunciação de Vencidos e Degenerados. Também para acréscimo de informações relevantes para o entendimento das formações discursivas e de todos os elementos que levarão à concepção de uma paratopia documento-testemunhal do discurso da negritude. É fato que nem $o$ enunciador, nem $o$ ethos e nem mesmo $o$ autor, como os concebemos nesta pesquisa, são a pessoa em si, contudo, essas concepções estão intimamente relacionadas aos efeitos de sentido possíveis depreendidos daquela realidade social.

Há um efeito paratópico que se sobrepõe à narrativa, o qual faz com que este discurso seja analisado por historiadores, sociólogos e antropólogos como se fosse um testemunho de uma época. Isso se dá, graças a uma atitude social e pessoal do enunciador, que além de construir uma imagem de autor, outorga um testemunho que se dá paratopicamente; para representar a voz do negro e preconizar o discurso da negritude.

29 Cf. capítulo VI. 
Essa atitude faz de José do Nascimento Moraes não somente um cidadão atuante e um escritor importante no universo maranhense, não somente uma voz de reação, mas também responsável por um discurso da negritude representativo no universo literário afrodescente e na (re)construção da memória negra nacional. Por essa razão, faz parte do cânone resgatado pela crítica literária contemporânea e seu discurso transformam seu(s) enunciador(es) em relevantes, porque a enunciação apresenta discursos ancestrais e prenuncia o Movimento da Negritude norte-americano e europeu, apresentados no capítulo anterior.

Conceituar a presença atuante do negro no universo intelectual-literário implica lidar não somente com questões sociais, culturais e políticas. Atualmente, significa resgatar na memória nacional uma gama gigantesca de autores relegados a segundo plano; significa romper com o purismo academicista que ignora a afrodescendência de Machado de Assis, por exemplo, para construir uma literatura negra e redefinir o panorama literário nacional, pois

enquanto muitos ainda indagam se a literatura afro-brasileira realmente existe, a cada dia a pesquisa nos aponta para o vigor dessa escrita: ela tanto é contemporânea, quanto se estende a Domingos Caldas Barbosa, em pleno século XVIII; tanto é realizada nos grandes centros, com dezenas de poetas e ficcionistas, quanto se espraia pelas literaturas regionais. Nesse caso, revela-nos, por exemplo, um escritor do porte de José do Nascimento Moraes, autor, entre outros, do romance Vencidos e Degenerados (1915), cuja ação tem início em 13 de maio de 1888 e se estende pelas décadas seguintes a fim de narrar a permanência da mentalidade derivada da escravidão. Enfim, essa literatura não só existe como se faz presente nos tempos e espaços históricos de nossa constituição enquanto povo; não só existe como é múltipla e diversa. (DUARTE, 2011:375)

Essa diversidade revela-se também nos diferentes discursos do enunciador que assume sua negritude, pois, para a crítica literária da atualidade, a literatura afrodescendente já não é somente aquela que fala sobre o negro de forma idealizada, mas também aquela do negro, para o negro e com o negro. Como revela Duarte (2011), na construção da memória afrodescendente a literatura desempenha o papel de reconfiguração discursiva dessas reminiscências, que se apresentam em diferentes matizes. ${ }^{30}$

30 Duarte (2011) ainda afirma que cabe avaliar o "estado da arte" de dois desses instrumentos: os conceitos de literatura negra e de literatura afro-brasileira. Para esses estudos, destaca ainda a importância dos trabalhos feitos por organizações como Quilombhojeem São Paulo; as publicações dos Cadernos Negros; a militância de Muniz Sodré, Nei Lopes e outros. E admite que há diferentes perspectivas dentro da Crítica Literária, partindo do negrismo modernista, de que são exemplos Jorge de Lima, Raul Bopp, Menotti del Picchia e outros, até a contemporaneidade, com os estudos de Benedita Gouveia Damasceno, Domicínio Proença e Zilá Bernd que denotam uma "nova ordem simbólica" e a "emergência de um eu enunciador". 
De imediato, impõe-se indagar: o que torna a escrita afro-brasileira distinta do conjunto das letras nacionais? Que elementos diferenciam e conferem especificidade à produção literária dos brasileiros descendentes de africanos? Descartados os fatores extra-literários, algumas constantes discursivas se destacam e têm sido utilizadas como critérios de configuração dessa literatura. Em primeiro lugar, a temática: "o negro é o tema principal da literatura negra”, afirma Octavio Ianni, que vê o sujeito afrodescendente não apenas no plano do indivíduo, mas como "universo humano, social, cultural e artístico de que se nutre essa literatura." (1988:54) Em segundo lugar, a autoria. Ou seja, uma escrita proveniente de autor afro-brasileiro, e, neste caso, há que se atentar para a abertura implícita ao sentido da expressão, a fim de abarcar as individualidades muitas vezes fraturadas oriundas do processo miscigenador. Complementando esse segundo elemento, logo se impõe um terceiro, qual seja, o ponto de vista. Com efeito, não basta ser afrodescendente ou simplesmente utilizar-se do tema. É necessária a assunção de uma perspectiva e, mesmo, de uma visão de mundo identificada à história, à cultura, logo, a toda problemática inerente à vida desse importante segmento da população. Nas palavras de Zilá Bernd (1988), essa literatura apresenta um sujeito de enunciação que se afirma e se quer negro. Um quarto componente situa-se no âmbito da linguagem, fundado na constituição de uma discursividade específica, marcada pela expressão de ritmos e significados novos e, mesmo, de um vocabulário pertencente às práticas linguísticas oriundas de África e inseridas no processo transculturador em curso no Brasil. E um quinto componente aponta para a formação de um público leitor afrodescendente como fator de intencionalidade próprio a essa literatura e, portanto, ausente do projeto que nortearia a literatura brasileira em geral. Impõe-se destacar, todavia, que nenhum desses elementos isolados propicia o pertencimento à Literatura Afro-brasileira, mas sim a sua interação. Isoladamente, tanto o tema, como a linguagem e, mesmo, a autoria, o ponto de vista, e até o direcionamento recepcional são insuficientes. (DUARTE, 2008:2, grifos nossos) ${ }^{31}$

Nos escritos de Nascimento Moraes, encontram-se esses elementos literários que não somente reiteram seu significativo papel na Literatura Afro-brasileira, mas também apresentam estratégias discursivas, cujos efeitos de sentido, denotam enunciadores representantes do discurso da negritude anteriormente apontado. A imagem que ele constrói de si é a imagem do enunciador que toma a palavra como arma de

31 Disponível em: <http://periodicos.unb.br/index.php/estudos/article/view/2017>. Acesso em: 27 mai. 2015. 
resistência social.

\subsection{Condições sócio-históricas de produção}

O discurso literário desse(s) enunciador(es) negros presentes em "Vencidos e Degenerados", sem dúvida, é herdeiro de um passado profícuo em terras maranhenses.

A intelectualidade maranhense carrega consigo essa herança que, provavelmente, surgiu com a presença do Pe. Antônio Vieira, que viveu em São Luís, pela Companhia de Jesus, de 1655 a 1662, data em que a Companhia foi expulsa. O religioso compôs poemas e sermões que exaltavam as riquezas naturais maranhenses. Ao mesmo tempo, alfabetizava e catequizava a população. Ainda que durante o período colonial, na ilha, só houvesse literatura de viagem, é pertinente destacar que, durante essa época de grande desenvolvimento agrário, muitos maranhenses estudaram na Europa. (BRANDÃO,1979).

Seguindo as tendências estilísticas da época ligadas à “imitação" dos modelos europeus, os maranhenses apresentaram rica produção literária, que mais tarde se consolidou e foi aprimorada, após $a$ Independência do Brasil, em 1822, ainda que o Estado só a tenha apoiado oficialmente em 1824.

É dessa realidade de riquezas agrária e intelectual, que perpassa o cerne da decadência econômica pós-abolição, e surge como resultado: a riqueza literária maranhense. Jomar Moraes, em sua obra Apontamentos de Literatura Maranhense, assim como outros historiadores, antropólogos e historiógrafos, opta por dividir a produção literária em três períodos (Quadro III). 


\section{Quadro IV - Grupos literários maranhenses}

\begin{tabular}{|c|c|c|}
\hline Períodos & Autores & Características \\
\hline $\begin{array}{l}\text { Grupo Maranhense } \\
(1832-1868)\end{array}$ & $\begin{array}{l}\text { Joaquim Serra, Gol- } \\
\text { çalves Dias, Sou- } \\
\text { sândrade, Odorico } \\
\text { Mendes, Gentil Bra- } \\
\text { ga, Sotero dos Reis, } \\
\text { Celso Magalhães, , } \\
\text { César Marques, João } \\
\text { Francisco Lisboa e } \\
\text { Maria Firmina dos } \\
\text { Reis }^{32}\end{array}$ & $\begin{array}{l}\text { Responsáveis pelo atributo Atenas } \\
\text { Brasileira a São Luís. Conviviam neo- } \\
\text { clássicos e românticos, jornalistas e } \\
\text { poetas. O jornalismo é fundamental para } \\
\text { a propagação literária. }\end{array}$ \\
\hline $\begin{array}{l}\text { Grupo dos Emigra- } \\
\text { dos }(1868-1894)\end{array}$ & $\begin{array}{l}\text { Aluísio Azevedo, } \\
\text { Coelho Neto, Rai- } \\
\text { mundo Correia, Ma- } \\
\text { nuel de Bethencourt, } \\
\text { Artur Azevedo, João } \\
\text { Afonso do Nascimen- } \\
\text { to, Euclides Faria, } \\
\text { Eduardo Ribeiro, Pa- } \\
\text { cífico Bessa e Marce- } \\
\text { lino Barata33 }\end{array}$ & $\begin{array}{l}\text { Assim chamados porque, pautados } \\
\text { pelo sucesso da Atenas Brasileira, mi- } \\
\text { graram para São Paulo, Rio de Janeiro } \\
\text { e Amazônia, durante o período do } \\
\text { realismo/naturalismo. Fazendo parte, } \\
\text { inclusive, do parnasianismo. }\end{array}$ \\
\hline
\end{tabular}

32 Considerada a primeira romancista brasileira, autora do romance social abolicionista Úrsula, descoberto por José Nascimento Morais Filho. Embora Jomar Moraes não a considere entre os grandes escritores maranhenses, mas "medíocre" e "desimportante", optamos por incluí-la nesse quadro adaptado, pois consideramos que o fato de ser mulher, negra e autodidata, numa sociedade patriarcal, influenciou a crítica geral da época. Além disso, consideramos que sua obra ainda é pouco explorada e obscura, o que torna a análise de Jomar Moraes relativamente precipitada.

33 Esses últimos foram apontados por Martins (2002) como parte do grupo dos emigrados para a Amazônia. 


\begin{tabular}{|c|c|c|}
\hline $\begin{array}{l}\text { Novos Atenienses } \\
(1894-1932)\end{array}$ & $\begin{array}{l}\text { Grupo inicial: Reis } \\
\text { Carvalho; Inácio } \\
\text { Xavier de Carvalho; } \\
\text { Euclides Marinho; An- } \\
\text { tonio Lobo; José do } \\
\text { Nascimento Moraes; } \\
\text { Domingos Barbosa } \\
\text { Outros autores: } \\
\text { Viriato Correia, Astol- } \\
\text { fo Marques, Alves de } \\
\text { Faria, Costa Gomes, } \\
\text { Maranhão Sobrinho e } \\
\text { outros }\end{array}$ & $\begin{array}{l}\text { O grupo compõe a Oficina dos Novos, } \\
\text { como movimento de reação à ausên- } \\
\text { cia de produções intelectuais causa- } \\
\text { das pelo êxodo. } \\
\text { O grupo divide-se, formando: } \\
\text { os neo-atenienses liderados por Antô- } \\
\text { nio Lobo, que funda a Academia Ma- } \\
\text { ranhense de Letras para reunir asso- } \\
\text { ciações literárias e grupos de jovens } \\
\text { intelectuais. } \\
\text { A Renascença Literária, liderada por } \\
\text { José do Nascimento Moraes. } \\
\text { Além do saudosismo e do resgate } \\
\text { do passado, esse período tem como } \\
\text { característica a forte utilização do dis- } \\
\text { curso jornalístico. Embates políticos } \\
\text { permeiam o estilo e a valorização do } \\
\text { vernáculo, assim como a defesa da } \\
\text { raça negra e população; além do cará- } \\
\text { ter republicano. }\end{array}$ \\
\hline
\end{tabular}

Adaptado de Moraes (1977), Martins (2002) e Meireles (1955/2001)

Embora nosso trabalho não tenha caráter historiográfico, ressaltamos que a Oficina dos Novos e, consequentemente, as condições sócio-hitóricas desse discurso literário, surgem em contextos histórico, econômico e político de instabilidade e decadência e validam o discurso dos enunciadores.

A abolição da escravidão leva à decadência da lavoura e à adesão da república, o que, em quase nada, beneficia o Estado, que não teve desenvolvimento comercial, ou industrial, planejado. O povo, oprimido por governos exploradores e sem acesso à educação, distancia-se ainda mais das demais classes sociais. Entretanto, a elite também não vivia mais sob os auspícios daquele passado glorioso, em que filhos de senhores estudavam na Europa, quando da formação do grupo da chamada Atenas Brasileira.

Em meio a tudo isso, José do Nascimento Moraes não somente imprime sua marca estilística como jornalista, mas também fortalece sua imagem como escritor e professor, defensor dos direitos do povo, lutador por um lugar social relevante, líder de grupos de esquerda, consciente de seu papel intelectual e de sua negritude. Suas ações sociais, seja como professor, seja como jornalista, fortalecem os argumentos do(s) enunciador (es) no discurso e paratopicamente os legitimam, por sua imagem de negro, literato, proficiente e lutador.

Essa postura arrojada cria conflitos e divergências políticas dentro do grupo da Oficina dos Novos e acaba por cindi-lo. Entretanto, ao contrário do que se pode pensar, essas rivalidades e inimizades enriqueceram as produções de Nascimento Moraes, da 
mesma forma que para os demais. Assim, além de retratar esse aspecto histórico-ideológico decadente, conferiu ao discurso um caráter contextualizador e contestador, principalmente em sua atuação como jornalista. O grupo de Nascimento Moraes fazia oposição ao governo e ao grupo dos neo-atenienses liderado por Antônio Lobo. Esses conflitos políticos também podem ser identificados nos diferentes gêneros do discurso da época.

\subsection{O jornalista: "Auto-proclamado um lutador”}

Até meados do século XVIII, não havia tipografias instaladas na Capitania do Maranhão. Todas as informações advinham de outras províncias ou diretamente de Portugal. Segundo Meireles (1992), há muitos fatores que podem explicar o atraso na chegada das tipografias ao território: a ocupação feita com descaso por parte dos portugueses; as invasões francesas e holandesas; o desenvolvimento econômico atrasado, pois até a Guerra de Secessão, nos Estados Unidos, todos os produtos eram exportados; a influência dos comerciantes lusitanos que mantinham a estrutura conservadora e escravocrata, fiel a Portugal e a população analfabeta em sua maioria.

No final do século, havia alguns pasquins que circulavam na ilha de São Luís, ainda advindos de outras regiões. Somente em 1821, é lançado O Conciliador, primeiro jornal do Maranhão. Contudo, suas primeiras edições eram ainda registradas a bico de pena, pois, segundo Jorge (1998:17), somente em 10 de novembro sairia a primeira edição impressa.

Será, então, o princípio do século XIX, marcado pelo início da imprensa no Maranhão. O Conciliador, todavia, apresentava linguagem agressiva e nada conciliadora. Jorge (1998) o considera o primeiro jornal oficial, que lutava por seus interesses, que eram, na verdade, os interesses lusitanos, de forma noticiosa, com linguagem bastante feroz. Os demais jornais surgiram com essa herança linguística, ainda que o contrariem ideologicamente, seguem ainda esse modelo.

Posto isso, somente em meados do século XIX tem-se no Maranhão o desenvolvimento jornalístico. Importante ressaltar que o jornal, em si, carrega essa herança de linguagem agressiva e aguerrida em que os jornalistas atacavam o regime, demarcavam seus lugares sociais e atacavam-se.

José do Nascimento Moraes nasce em 19 de março de 1882 e cresce em meio a essa transição e incorporação social do gênero jornalístico. Autodidata, jornalista, professor de Português, no Liceu, e Matemática, para o curso Normal, escreve em muitos jornais de São Luís do Maranhão, como O Correio da Tarde, O Diário, Jornal do Maranhão, e outros. Cria uma imagem de si no discurso que reflete o enunciador que dá voz ao negro oprimido e luta por seus direitos sociais. 
Encontramos com Nascimento Moraes muito antes de encontrarmos sua paratopia discursiva, ou sua obra, pois ele está nas paredes da São Luis Histórica, nas ruas do Trapiche, na Rua Grande. Enfim, em toda parte, é possível imaginar o velho professor em sua grandiosidade, subindo as ruas, cumprimentando conhecidos e seguindo em direção a louváveis jornais que, a princípio, acolheram sua intelectualidade inquieta; em seguida, foram manejados, modernizados, acolhidos e mantidos economicamente com suas palavras criativas, sua liderança e seu olhar ferino para a realidade do povo.

Também o encontramos na Biblioteca Benedito Leite, na Biblioteca Nacional e na sala de estudos e leituras da Academia Maranhense de Letras, com a qual discutia, discorria, criticava, partilhava saberes, discordava e rompia. Seu espírito literário, sua crítica jornalística, estão lá, para quem o conhece um pouco, vivos em cada mesa de bar, em cada tertúlia, cuja ausência ainda é sentida. Grande polígrafo, crítico e ativista social, filho de Manoel do Nascimento Moraes e Maria Catarina Vitória.

O pai nasceu em 1839, também ludovicense; capoeirista de primeira, tinha como apodo Currupira, por ser conhecido no bairro da Currupira, formado pelas Rua das Hortas, Rua do Outeiro e Camboa. Ainda lutou na Guerra do Paraguai, de onde voltou lesionado em uma das pernas. Não foi condecorado por ato de bravura como os demais, nem recebeu soldos da Guerra, por ser analfabeto. Fato já registrado por muitos historiadores, de que o negro seria usado como "bucha de canhão", com promessas de libertação, soldos e prestígio nunca cumpridas.

Após a desilusão do retorno, trabalhava como sapateiro para sustentar a família e jurou que seus filhos saberiam ler e escrever. ${ }^{34}$ Aprendeu a ler sozinho, anos depois, quando trabalhou como servente do Tesouro Nacional, lendo artigos de jornais.

A mãe, D. Catarina Vitória (a vó Babá), nasceu em São Luís e tem presença muito forte na obra de Nascimento Moraes. Era lavadeira e cozinheira da sociedade branca aristocrática. Por meio de seu carinho e de seus diálogos com o filho, D. Catarina Vitória transmite experiências e histórias vistas e vividas, que serão reproduzidas nos textos dele; o que pode ser percebido em seus muitos artigos, sob o pseudônimo de Valério Santiago, no Correio da Tarde, como no recorte "uma preta com o seu alvará de libertação da escravatura" 35 .

$34 \quad$ Em entrevista concedida para Eliana Campos Morais Rêgo, para sua monografia de Conclusão do Curso de Letras da Universidade Estadual do Maranhão (Uema), feita na década de 90, e intitulada O Perfil de um Negro, na Primeira Metade do Século XX, em São Luís do Maranhão: José do Nascimento Moraes, defendida em 1997, cedida para nossa pesquisa pela família Morais, representada por seus netos Loreley Nascimento Morais e Renan Nascimento Morais, José Nascimento Morais Filho (1922-2009) relata que, ao ser rechaçado para a condecoração, seu avô jurou intimamente que seus filhos "seriam doutores". Esse fato também é relatado por Paulo Nascimento Moraes na obra Contos de Valério Santiago, publicada pelo Serviço de Imprensa e Obras Gráficas do Estado (Sioge) em 1972, onde há a descrição das atitudes do general Osório, responsável pela condecoração dos sobreviventes, que ordenou que somente os que soubessem ler, escrever e contar deveriam se apresentar, dando um passo à frente.

35 Essa caracterização da mãe e de muitas personagens em seus diferentes textos pode ser encontrada na coluna Puxos e Repuxos, em Vencidos e Degenerados na descrição da perso- 
Nos seus escritos, reinam histórias de sua infância e da relação familiar com seu irmão Raimundo Nascimento Morais, homem público e também escritor. Nesses textos, são reveladas características da sociedade em que viveu, com destaque dos aspectos culturais, políticos e psicológicos. Encontram-se descritos, em detalhes, as ruas, os casarios, as relações de poder, os problemas sociais e as relações familiares. Ora utiliza pseudônimos (são mais de dez identificados socialmente), ora assume a autoria, ora nomeia personagens com nomes de pessoas de seu convívio, ou construindo caracterizações e personagens.

Frequentou somente a Educação básica, no Liceu Maranhense, lugar onde mais tarde lecionou para a elite maranhense, incluindo José Sarney e Ferreira Gullar. Também ministrou aulas particulares, segundo Machado (1982:9), "iniciou suas atividades jornalísticas sob a orientação e o incentivo do professor Manuel Bithencourt”, preceptor de jovens, conhecido largamente na sociedade maranhense por promover discussões literárias a partir das leituras de Tolstoi, Turgueniev, Ibsen, Strindberg, Dickens, Zola e Eça de Queirós.

\section{José do Nascimento Moraes viveu uma época atrelada à tute- laridade historicista de Spencer e ao cientificismo evolucionista de Darwin, onde o mundo como vontade e representação era anquilosado pelo pessimismo de Schopenhauer, vertentes, os três, da poesia noturna e angustiada de Augusto dos Anjos (...) (MA- CHADO, 1982:11)}

Idealista e sonhador, fez parte do grupo que fundou a Academia Maranhense de Letras. Boêmio, teve muitas mulheres em sua vida ${ }^{36}$, mas, oficialmente, são mencionadas apenas duas. A primeira foi Dona Ana Augusta (vó Sinhá), filha de criação de Pacífico da Cunha. Fazia parte da elite branca maranhense, era culta, falava francês fluentemente e tocava piano. Com ela, teve quatro filhos: Ápio Cláudio do Nascimento Moraes, Paulo Augusto Nascimento Moraes, Nadir Adelaide do Nascimento Moraes e João José do Nascimento Moraes. Sua segunda união ocorreu de forma conturbada, pois começou em sua casa, quando recebeu Dona Maria Francisca da Graça Bogéa para prosseguimento dos estudos dela. Ela vinha do interior do Maranhão, da cidade de Arari e pertencia à Aristocracia rural.

nagem Andreza, mãe do protagonista Cláudio e também aparece na coletânea crítica de Paulo Nascimento Morais Contos de Valério Santiago, publicada pela Sioge, em 1972 (p. 219).

36 Em entrevista concedida para esta pesquisa, em novembro de 2013, o neto Renan de Moraes o descreveu como um espírito forte e desbravador, à frente de seu tempo e já preocupado com questões ambientais. Em abril de 2014, estivemos com Lorelei Nascimento Moraes, que falou sobre esse aspecto da personalidade do avô, dizendo que, por ser intelectual e politicamente ativo, encantava as senhoras e senhorinhas de todas as classes do Maranhão, inclusive, apaixonando-se por algumas de suas alunas. Jomar Moraes, único contemporâneo vivo, que nos recebeu na biblioteca de sua casa para um contato, no primeiro semestre de 2013 , ao se referir às mulheres na vida de Nascimento Moraes, disse "Ele tinha esse bom gosto". 
Dessa união, nasceu José Nascimento Morais Filho ${ }^{37}$, que foi educado por Dona Augusta, entregue a ela com um dia de nascido, pois Nascimento Moraes foi acusado, por parte da família aristocrata, de sedução de menores. Contudo, essa relação perdurou e foi a causa de sua separação. Com a segunda mulher, teve mais cinco filhos, mas somente sobreviveram Talita Moraes e Raimundo Morais, em homenagem a seu irmão Raimundo Moraes, com quem fundou o Instituto de Ensino Nascimento Moraes.

Em meio à constituição familiar e desavenças amorosas, desenvolveu sua intensa vida profissional. Nascimento Moraes escreveu em quase todos os jornais de São Luis, como colaborador ou redator-chefe, como A Campanha, O Maranhão, A Pátria, Diário de São Luís, O Jornal, A Tribuna, A Hora, Diário do Norte, Diário Oficial, Correio da Tarde, A Imprensa, Regeneração, Diário do Maranhão, O Imparcial e outros. Quase sempre oposicionista, cedeu parcialmente ao Estado-Novo, que o nomeou redator chefe do Diário Oficial do Maranhão, por seu prestígio jornalístico. Embora continuasse a expor as deficiências e mazelas do governo. Ao trabalhar

num período político que se estendeu dos governos de Benedito Leite até um pouco antes da gestão de Eugênio de Barros (1951/1956), Nascimento Moraes atravessou, quase sempre acirrada oposição, nos governos, entre muitos outros (sobretudo da fase intervencionista), de Herculano Nina Parga(1914/1918), Urbano da Costa Araújo (1918/1922), Godofredo Viana (1922 a 1926), José Maria Magalhães de Almeida (1926 a 1930), José Maria Reis Perdigão (27.11.30 a 9.1.31), Seroa da Mota (8.9.1931 a 10.2.1933), Aquiles Lisboa (1935/1936), Paulo Martins de Souza Ramos (24.11.1937 a 23.3.1945), Eleazar Soares Campos (9.11.1945 a 16.2.1946), Saturnino Belo (16.2.1946 a 10.4.1947), e poucos outros. (MACHADO, 1982:9-10) ${ }^{38}$

Defendia os interesses da intelectualidade da época, formava grupos de discussão literária e já atuava no magistério, imaginando uma pedagogia dinâmica voltada à

37 Importante salientar que não há uma grafia unânime nos sobrenomes dos componentes da família Moraes, obviamente, por questões fonéticas transferidas à grafia. Do mesmo modo, percebemos a ausência da preposição em alguns nomes de familiares, ou seja, em vez de "do Nascimento", somente "Nascimento Moraes". Segundo o depoimento dos netos e familiares, o nome de Nascimento Moraes seria José Nascimento Moraes, mas não sabem por quê passou a assinar José do Nascimento Moraes. Acreditamos que seja resquício da divisão de classes que começou nas cartas de alforria e ainda mais a partir da Lei Eusébio de Queirós, em que os negros, em seus documentos, eram registrados com os sobrenomes de seus antigos senhores, daí a utilização da preposição de propriedade e origem de/do/da, durante certo tempo, diferenciava-se socialmente o liberto e o alforriado pela presença dessa partícula, fato que já vinha ocorrendo com sobrenomes toponímicos portugueses e patronímicos dos cristãos novos; depois se tornou uma espécie de "vício de linguagem", identificador/ diferenciador de negros e brancos.

$38 \quad$ Nauro Machado, poeta e escritor maranhense, escreveu ensaio brilhante e minucioso, intitulado A Escrita Polêmica de José do Nascimento Moraes, como Prefácio para a segunda edição da obra Neurose do Medo e 100 artigos, obra esgotada. Nele, classifica Moraes como um escritor outsider e o jornalista mais importante das primeiras cinco décadas da história do jornalismo maranhense. 
práxis, lutava por ela e defendia os direitos do negro. Enfrentava com palavras e com ações sociais à sociedade em geral. Com esse posicionamento político, auto-proclamava-se um lutador, em vários pronunciamentos, discursos oficiais e textos jornalísticos. Seu único romance foi Vencidos e Degenerados, escrito em 1913 e publicado em 1915. Os outros livros que lhe são atribuídos são coletâneas de seus textos jornalísticos organizados em: Neurose do Medo e 100 Artigos; Puxos e Repuxos; e Círculos (ainda inédito). Esse último consta da documentação e pesquisa de seu filho José Nascimento Morais Filho. ${ }^{39}$

\subsection{Produção}

\subsubsection{Puxos e Repuxos}

Esses foram os primeiros enunciados com os quais tivemos contato, antes mesmo de lermos o livro organizado postumamente, pois todos os textos jornalísticos do Maranhão encontram-se digitalizados e disponíveis na Internet. ${ }^{40}$ Para analisar a produção de Nascimento Moraes, por meio de uma perspectiva voltada para AD, fizemos com essa obra algumas análises que serviram como base para a análise de Vencidos e Degenerados. ${ }^{41}$ Apresentamos, a seguir, Puxos e Repuxos e uma análise como ilustração de algumas categorias a serem utilizadas na análise final.

\subsubsection{Puxos e Repuxos: o fluxo linguageiro do relato de Valério Santiago}

O Correio da Tarde assumia claramente postura republicana progressista. Seu discurso atestava o posicionamento contra os escravocratas e conservadores, como os do jornal A Pacotilha. De sorte que muitos jornalistas criavam pseudônimos, como forma de manter a tradição adquirida dos portugueses de escrever desta forma e, sobretudo, como estratégia contratual comunicacional de proteção da face para "atacar" o outro sem identificação direta, ainda que, muitas vezes, fossem de domínio público, suas identidades originais.

Nascimento Moraes utilizava vários pseudônimos e mais de dez são conhecidos. Analisamos os textos escritos sob o pseudônimo Valério Santiago, na coluna Fluxos e Refluxos (posteriormente denominada Puxos e Repuxos) como réplica aos textos de Antônio Lobo, autor conservador, tradicionalista, racista e reprodutor de um pensamento ainda escravocrata do jornal A Pacotilha e reconhecemos o discurso jornalístico

39 Conforme relato de sua neta, Loreley Nascimento Morais, em entrevista aberta.

40 Disponível em: <http://bndigital.bn.br/hemeroteca-digital/> e <http://www.cultura.ma. gov.br/portal/bpbl/acervodigital/>. Acesso para consulta e pesquisa durante todo o doutorado.

41 Parte dos resultados desta análise foi apresentada no Grupo de Pesquisa Discursos na Mídia Escrita (Dime-PUC) em outubro de 2013. 
do autor.

Até a edição 00192, de 1910, a coluna escrita por Nascimento Moraes chamava-se Fluxos e Refluxos, composta ainda por texto distribuído em, no máximo, duas colunas. Apartidário, mas extremamente politizado, Moraes cria o pseudônimo Valério Santiago que, a princípio, faz comentários gerais sobre as publicações de A Pacotilha e alguns acontecimentos políticos que envolvem o grupo responsável pelo jornal, incluindo-se nele o governador da comarca. Sua crítica segue o caminho do dito relatado (CHARAUDEAU, 2007) em que o conhecimento dos fatos vai sendo narrativizado, seguindo o caminho diegético. ${ }^{42}$

O pseudônimo não somente mascara o verdadeiro enunciador, mas também cria um novo enunciador, o qual revela a herança do discurso dos jornais do século XVIII, cujos escritores criavam pseudônimos para escrever em jornais; também revela a instituição do primeiro movimento discursivo, ao criar a encenação, necessária para valorizar o seu dizer.

Com isso, narrativiza e descreve os co-enunciadores e coenunciadores d'A Pacotilha, quase como personagens surreais. Ora ataca diretamente Antônio Lobo, e utiliza somente seu sobrenome, ora utiliza seu pseudônimo Galliza, de modo que essa contenda cresce e, na edição 00193, de 27 de julho de 1910, a coluna passa a se chamar Puxos e Repuxos, em que o texto surge maior, mais encorpado, com três colunas ou mais, diretamente dirigido à réplica a Lobo.

Princípios como fato relatado, dito relatado e discurso relatado de Charaudeau (2007-2012) são significativos para a análise do topos jornalístico, na construção do espaço discursivo e da encenação genérica para verificar como o dito relatado revela as condições sócio-históricas de produção da época por meio das estratégias linguísticas, cuja base teórica apresentamos a seguir.

O dizer jornalístico carrega dimensões histórico-ideológicas que permearão as características do discurso do jornal e dos sujeitos que o compõem, bem como as estratégias de composição. Assim, o discurso contido nos jornais do século XVIII refletia a subserviência da colônia em relação aos padrões europeus e à defesa de seus valores. Uma vez que o Maranhão, enquanto capitania, ainda se constituía, a ausência de tipografias e a existência de jornais artesanais, compostos por jesuítas, revelam a posição dos sujeitos em relação à nação que se formava. Já no século XIX, a linguagem é o elemento propulsor dessa composição, porque ainda não havia a presença maciça de imagens em quantidade para o registro dos fatos.

"A imprensa diária no século XIX era essencialmente o vetor da palavra do político ou do cidadão na tribuna. No começo do século XX, confundiu-se com frequência com o partido de que era porta-voz." (MOUILLAUD e TÉTU, 1989 apud CHARAUDEAU, 2006: 68). Ou seja, o poder da palavra era ainda mais forte porque tanto reve-

$42 \quad$ A diegese é a "narrativização discursiva", a qual, nesse pseudônimo, é tão proeminente que há uma obra intitulada Contos de Valério Santiago. 
lava certa ideologia ou representação política, quanto se esforçava para criar o efeito de veracidade, por meio das diferentes operações de seleção para a composição textual sem o auxílio de imagens ou técnicas apuradas de impressão. A palavra compunha a encenação necessária para a concepção da mensagem. Charaudeau (2006) afirma que os dispositivos de construção de sentidos no ato de comunicação estão centrados nos sujeitos "falantes".

Tais dispositivos comporão a encenação genérica num movimento de alocução, quando há influência do locutor em relação ao interlocutor; de elocução, quando o discurso parte do locutor consigo mesmo; e de delocução, quando expõe seu posicionamento sobre/com um terceiro.

Em toda sociedade a produção do discurso está controlada, selecionada e redistribuída por um certo número de procedimentos que têm por função excluir poderes e perigos, dominar o acontecimento aleatório e esquivar sua pesada e temível materialidade.

(FOUCAULT,1998: 34)

Ao esquivar-se da materialidade discursiva, os sujeitos utilizam estratégias que vão do plano do enunciado ao situacional e vice-versa (Quadro IV).

\section{Quadro V - Plano enunciativo versus plano textual.}

\begin{tabular}{|l|l|l|}
\hline \multirow{3}{*}{$\begin{array}{l}\text { Plano do Enuncia- } \\
\text { do Elementar }\end{array}$} & Situação de enunciação & Situação de locução \\
\cline { 2 - 3 } & $\begin{array}{l}\text { Enunciador/coenunciador } \\
\text { Não-pessoa }\end{array}$ & $\begin{array}{l}\text { Locutor/alocutário } \\
\text { Delocutor }\end{array}$ \\
\hline \multirow{3}{*}{ Plano do Texto } & Situação de discurso & \\
\cline { 2 - 3 } & Ponto de Vista Externo & $\begin{array}{l}\text { Ponto de Vista interno } \\
\text { Cena de enunciação }\end{array}$ \\
\cline { 2 - 3 } & Situação de Comunicação & $\begin{array}{l}\text { Cena englobante } \\
\text { Cena genérica } \\
\text { Cenografia }\end{array}$ \\
\hline
\end{tabular}

\section{Adaptado de Maingueneau (2007:207)}

Ao compor essa encenação, seja no século XVIII, seja na atualidade, os jornais já utilizam, em cada caso de comunicação midiática, os modos de organização do discurso, apontados por Charaudeau (2006) como: relatar, comentar e provocar confrontos de ideia, ainda que não haja a presença maciça da imagem e de outras mídias como a $\mathrm{TV}$, o rádio e a Internet. 
Relatar o acontecimento, que compreende fatos e ditos, tem como consequência construí-lo midiaticamente. O fato relatado é objeto de descrição, de explicação e reações, ou seja, trata-se de relatar um acontecimento a partir da construção de uma narrativa. A narrativa midiática impõe o problema da linha tênue entre realismo e ficção para o sujeito que vai relatar. (CHARAUDEAU, 2006).

O dito relatado faz parte da linguagem humana, uma vez que "todo fato de linguagem poderia ser considerado um discurso relatado" (CHARAUDEAU, 2006:161).

O discurso relatado, por sua vez, emana da encenação e da interação entre os sujeitos do dizer, somados ao fato e ao dito relatado para construir/ reconstruir ou desconstruir o que foi dito. Para Charaudeau (2006), o discurso relatado se constrói a partir da dupla operação reconstrução/desconstrução, tanto em relação ao outro, quanto a si mesmo.

Espera-se que a instância midiática utilize a descrição, a explicação (diegetizada) e apreciações para a constituição de um "ponto de vista" (CHARAUDEAU, 2006: 158). Chega-se, assim, a uma inter-relação entre acontecimento midiático, desmembrado em acontecimento relatado, comentado e provocado (Quadro V).

\section{Quadro VI - Composição do acontecimento midiático}

\begin{tabular}{|l|l|l|}
\hline \multicolumn{3}{|c|}{ Acontecimento Midiático } \\
\hline $\begin{array}{l}\text { Acontecimento } \\
\text { Relatado }\end{array}$ & $\begin{array}{l}\text { Construção de um espaço temá- } \\
\text { tico rubricado/noticiado/tratado }\end{array}$ & $\begin{array}{l}\text { Fato relatado } \\
\text { Dito relatado }\end{array}$ \\
\hline $\begin{array}{l}\text { Acontecimento } \\
\text { Comentado }\end{array}$ & $\begin{array}{l}\text { Construção de um espaço } \\
\text { Problematizado }\end{array}$ & Análise comentário \\
\hline $\begin{array}{l}\text { Acontecimento } \\
\text { Provocado }\end{array}$ & $\begin{array}{l}\text { Construção de um espaço de de- } \\
\text { bate público externo às mídias }\end{array}$ & $\begin{array}{l}\text { Tribunas, entrevistas e } \\
\text { debates }\end{array}$ \\
\hline
\end{tabular}

\section{Adaptado de Charaudeau (2006:151)}

Observamos que as características discursivas de Nascimento Moraes no Correio da Tarde, na coluna Fluxos e Refluxos, posteriormente, Puxos e Repuxos, na qual responde às ofensas de Antônio Lobo, também literato maranhense, escravocrata e republicano, que escrevia no jornal A Pacotilha, sob o pseudônimo D. Galiza. Ambos, Santiago Valério e D. Galiza, se ofendiam e digladiavam com palavras duras e adjetivos nada tênues, cujos posicionamentos políticos em relação à Abolição e ao estilo de cada um deles como autores se reforçavam.

Esse duelo linguageiro dá-se de forma agressiva e faz lembrar o jornal $O$ Conciliador. Todavia, esse estado de violência gerado pela contenda, aparentemente, faz 
aumentar o número de leitores, uma vez que a coluna torna-se praticamente um "folhetim", cujo conflito pode ser acompanhado durante as edições posteriores. Assim, na organização de seu dizer, o enunciador conjuga os elementos apontados por Charaudeau (2006) como organizadores do ato comunicacional na mídia: relata, comenta e provoca conflitos de ideias.

Retomando o quadro adaptado de Maingueneau (2008) e aplicando-o à análise discursiva do enunciador aos recortes dos textos jornalísticos de Moraes, chegamos ao Quadro VI. 
Quadro VII - Análise ilustrativa do discurso jornalístico de Puxos e Repuxos

\begin{tabular}{|c|c|c|}
\hline \multirow[b]{2}{*}{$\begin{array}{l}\text { Plano do Enuncia- } \\
\text { do } \\
\text { Elementar }\end{array}$} & Situação de enunciação & Situação de locução \\
\hline & \begin{tabular}{|l|} 
Enunciador/coenunciador \\
Não-pessoa \\
Constitui-se na voz do ne- \\
gro enunciador que tem como \\
coenunciador todos os outros \\
negros e escritores defensores \\
da abolição, representado pela \\
figura do pseudônimo
\end{tabular} & $\begin{array}{l}\text { Locutor/alocutário } \\
\text { Delocutor } \\
\text { Valério Santiago assume o } \\
\text { papel de locutor/ Moraes é o } \\
\text { alocutário e alternam-se, nos } \\
\text { papéis de delocutores, Mo- } \\
\text { raes, Santiago, Lobo e Galli- } \\
\text { za }\end{array}$ \\
\hline \multirow[b]{2}{*}{ Plano do Texto } & $\begin{array}{l}\text { Ponto de vista externo } \\
\text { Constrói-se a partir da interlocu- } \\
\text { ção entre a conjuntura política e } \\
\text { o discurso de ambos }\end{array}$ & $\begin{array}{l}\text { Ponto de vista interno } \\
\text { enunciação: ocorre por meio } \\
\text { do discurso relatado }\end{array}$ \\
\hline & \begin{tabular}{|l|} 
Situação de comunicação \\
Nascimento Moraes versus An- \\
tônio Lobo = Valério Santiago \\
versus D. Galiza. Situação cria- \\
da por posicionamentos políti- \\
cos distintos em que Moraes é \\
nitidamente abolicionista e re- \\
publicano, enquanto Lobo é re- \\
publicado, porém conservador, \\
escravocrata e racista
\end{tabular} & $\begin{array}{l}\text { Cena englobante: Composta } \\
\text { por réplicas e tréplicas que } \\
\text { criticam a situação do Ma- } \\
\text { ranhão expostas pelo olhar } \\
\text { simplista dos jornalistas de } A \\
\text { Pacotilha,, sobretudo Antônio } \\
\text { Lobo, criando uma Arena } \\
\text { Cena genérica: coluna do jor- } \\
\text { nal Correio da Tarde do Ma- } \\
\text { ranhão } \\
\text { Cenografia: luta/debate políti- } \\
\text { co-literário. }\end{array}$ \\
\hline
\end{tabular}


No plano do enunciado elementar, apreendemos um discurso de contestação que instaura o discurso de todos os homens negros, difamados e insultados por homens como D. Galiza/Lobo e para divulgar o acontecimento midiático. Nesse caso, em suas réplicas às críticas infundadas, Santiago Valério une/interpola as três dimensões do dizer, expostas no Quadro VI, ou seja, tematiza/relata, problematiza/comenta e debate/provoca. Utiliza um linguajar carregado de analogias, ironias e comparações; imprime no dito relatado o discurso relatado de sujeitos letrados e literatos, cujos princípios e ideologias divergem.

Importante é ressaltar que a sequência do acontecimento, enquanto debate político, depende intrinsicamente do ponto de vista exterior, uma vez que é preciso conhecer a contenda para analisar os âmbitos enunciativo e o textual. Para exemplificar as estratégias de Valério Santiago, recorremos a categorias extraídas de Charaudeau (2006) e aplicamos ao texto da edição 00197 de 1o de agosto de 1910 (Quadro VII). 
Quadro VIII - Análise ilustrativa das modalidades locucionais.

\begin{tabular}{|c|c|}
\hline \multicolumn{2}{|r|}{ Modalidades Alocutivas } \\
\hline Interpelação & $\begin{array}{l}\text { 1. [Negro! Eis ahí o insulto, a palavra com que elles } \\
\text { pensam que nos esmagam, que nos reduzem à úl- } \\
\text { tima expressão.] }\end{array}$ \\
\hline Injunção & $\begin{array}{l}\text { 2. [Si Lobo demonstrar esse pedacinho de oiro que ahí } \\
\text { ficou acima, não Ihe chamaremos mais de Bôbo! } \\
\text {.] }\end{array}$ \\
\hline Julgamento & $\begin{array}{l}\text { 3. [Na verdade, é digno de nota que um homem, que } \\
\text { um homem talentoso e de muito saber, escreva ver- } \\
\text { sos ameaçando de chicote, relho crú etc. o adver- } \\
\text { sário!!!]. }\end{array}$ \\
\hline \multicolumn{2}{|r|}{ Modalidades Elocutivas } \\
\hline Constatação & $\begin{array}{l}\text { 4. [Eis ahí uma afirmativa que Lobo não prova, uma } \\
\text { proposição que elle não demonstra.] }\end{array}$ \\
\hline Opinião & $\begin{array}{l}\text { 5. [Sujeitos que se dizem representantes das letras } \\
\text { maranhenses...] }\end{array}$ \\
\hline Apreciação & $\begin{array}{l}\text { 6. [Estamos satisfeitíssimos com essa amostra que } \\
\text { deram do seu elevado preparo e grandeza intellec- } \\
\text { tual e moral.] }\end{array}$ \\
\hline \multicolumn{2}{|r|}{ Modalidades Delocutivas } \\
\hline Asserção & $\begin{array}{l}\text { 7. [Para se saber quem foi que elle insultou, basta } \\
\text { que nos diga qual é a elite do Maranhão!!!] }\end{array}$ \\
\hline $\begin{array}{l}\text { Discurso relata- } \\
\text { do }\end{array}$ & $\begin{array}{l}\text { 8. [Durante o relato, Santiago Valério cita partes do li- } \\
\text { vro de Lobo para criticá-lo, fazendo uso de citações, } \\
\text { evoca outros autores e autoridades e integra o dis- } \\
\text { curso do outro ao seu discurso.] }\end{array}$ \\
\hline
\end{tabular}

Adaptado de Moraes (1910, s/n)

No decorrer do discurso relatado, Santiago abusa da ironia para conseguir a adesão do leitor para este e para o próximo texto: inicia com [Um pequeno cavaco antes de continuarmos o esphacelamento de mais uma obra de Antonio Lobo] e finaliza com [E a pancadaria continuará a descer amanhã] (MORAES, 1910, s/n).

No melhor estilo sensacionalista, demonstra aos novos leitores, com a utilização do verbo continuar, que esse [esphacelamento] já começou e não terminou. A utilização das metáforas [esphacelamento] e [pancadaria] reforça a encenação discursiva de embate/luta/contenda. 
Percebemos, assim, por meio da escrita de Nascimento Moraes que, no Maranhão, em pleno século XIX, muitas características dos pasquins manuscritos do século XVIII persistem; não como imposição ou demérito, mas como herança discursiva constitutiva que domina um estilo. Entretanto, a linguagem jornalística e o contrato comunicacional midiático já apresentam características próprias e fortemente instauradas, uma vez que não há a imagem como apoio.

A partir do que foi dito sobre $O$ Conciliador, que preconizava e defendia a constituição lusitana de forma aguerrida e nada conciliadora, somando à maneira como a coluna Puxos e Repuxos vai se tornando uma "arena" entre Nascimento e Lobo, ou entre Valério Santiago e D. Galiza, temos, aí, as condições sócio-históricas de produção denunciadas pelo meio em que o autor foi educado e pelo contexto em que viveu. Dessas condições, surge uma enunciação que, aparentemente, inova a proposta do jornal O Conciliador.

Se, por um lado, inova ao criar um discurso jornalístico-literário, cujo dito relatado exegético ${ }^{43}$ é pormenorizado, e recria sentimentos e fatos, por outro, mantém postura semelhante ao $O$ Conciliador, que segue o modelo da época para expor sua opinião. Isto é, utiliza o modelo, mas inova ao defender claramente seu posicionamento republicano progressista e por já preconizar posturas que serão defendidas pelos Movimentos Negros da atualidade.

O preconceito contido no discurso de D. Galiza cria um estado de violência reconstituído e reiterado verbalmente, de tal modo que Valério Santiago, em suas réplicas e tréplicas, vai, gradativamente, aumentando seu ardor e suas ironias se tornam sarcásticas, cada vez mais ofensivas e são corriqueiras palavras como: [destruir, esphacelar, pancadaria, torpe, idiota, imbecil, vil e outras]. À utilização do termo [Negro], Valério Santiago responde (Fig.3):

43 Charaudeau (2006) utiliza o termo exegético ao dizer que funciona como explicação ou comentário, ampliando o significado teológico original do termo (relativo à exegese bíblica). 
Figura 3.- Recorte extraído de Correio da Tarde

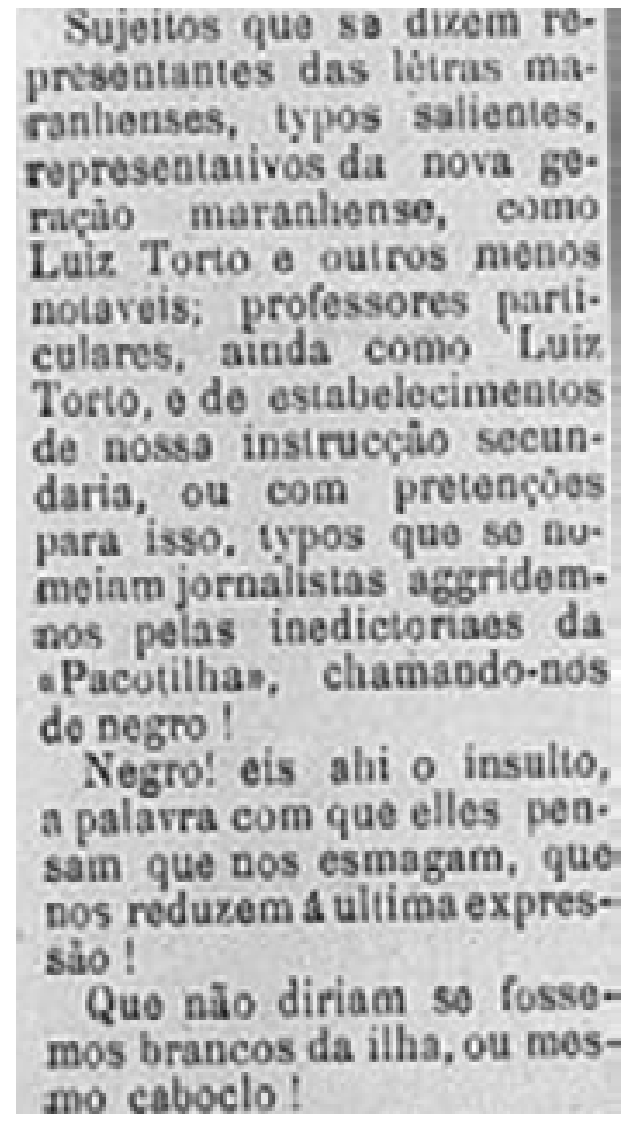

Fonte: Correio da Tarde. São Luis do Maranhão, 1a ago. 1910, Ed. 00197.

Utiliza, em sua resposta, a estratégia de delocução em [Sujeitos que se dizem representantes das letras...] (MORAES, 1910, s/p) e também faz uso da alusão ao dizer de D. Galiza no jornal A Pacotilha. Nessa mesma coluna, dirá que [Negro é aquele que todo mundo sabe insultar] (MORAES, 1910, s/d)], assim, utiliza a palavra do outro para diminuir seu discurso, inferiorizar sua posição e partir de uma suposta posição social particular a uma posição generalizada. Com esse movimento, aos poucos, o cenário vai se tornando agressivo e violento. Contudo, não somente a contenda política mantém o discurso da violência; reproduz ideologias da época, e também demonstra que o preconceito é um estado de violência.

Há violência quando, numa situação de interação, um ou vários atores agem de maneira, direta ou indireta, maciça ou esparsa, causando danos a uma ou várias pessoas em graus variáveis, seja em sua integridade física, seja em sua integridade moral, em suas posses ou em suas participações simbólicas e culturais. 
Valério Santiago é agredido durante a situação de comunicação criada pela coluna e revida com a crítica à obra de Antônio Lobo e de seus pares, bem como sua posição social e profissão. Por sua vez, D. Galiza (Lobo) critica a condição humana de Santiago, identificando-o e confrontando-o com o estereótipo do negro na visão dos republicanos conservadores. Segundo Cano (2012), o reforço de estereótipos negativos confirma e reinstaura estados de violência.

Para finalizar, ao observarmos a constituição do contrato social que cria a encenação de uma verdadeira arena, o linguajar e as figuras de linguagem, sobretudo as metáforas e as ironias, percebemos o prenúncio de uma linguagem jornalística sensacionalista, uma vez que o debate político-ideológico acaba por ampliar as dimensões do dizer de forma exagerada, quase hiperbólica, fato que, provavelmente, fomentava também a popularização e a venda do jornal.

$\mathrm{Na}$ análise de Puxos e Repuxos, reconhecemos "o lugar do dizer jornalístico" na vida de Nascimento Moraes, em que o discurso da negritude se manifesta na forma como esse enunciador se assume negro discursivamente, apresenta o negro discursivamente, apresenta diversos pontos de vista que abarcam a temática da africanidade e interage na busca de interlocutores negros, ou que se identifiquem com as questões que os envolvem.

É dessa postura e dessa experiência com o pseudônimo Valério Santiago que surge a obra Contos de Valério Santiago, publicada pela primeira vez em 1972 e reeditada em 1982 pela Secretaria de Educação e Cultura do Maranhão, com Vencidos e Degenerados, em único exemplar. Nesta edição, encontramos 21 contos intitulados:

$>$ A vida de um homem de bem;

$>$ O caso de dona Florinda;

$>$ O "monstrinho" de dona Filomena;

$>$ A preta Benedita;

$>$ A canção que ainda não morreu;

$>$ Uma lição proveitosa;

$>$ Um homem singular;

$>$ Estranho caso;

$>$ Desmoronamento;

$>$ “Tu, só tu, puro amor...";

$>$ O primeiro beijo;

$>$ Sacrifício;

$>$ Por sobre os saibros;

> Um homem diabólico;

> Madame Andréia Schandley;

> João Amâncio Sarará;

$>$ Um conselho de família;

$>$ Dona Aniquinha; 


\section{$>$ Ladrões!...; \\ $>$ A decepção de Chico Pastinha; \\ $>$ Os mirantes de São Luís.}

Se, nos artigos publicados em resposta a Antônio Lobo, há um enunciador que se assume negro para defender sua condição social e seus direitos, em Contos de Valério Santiago o enunciador muda o ponto de vista e passa a falar sobre o negro na sociedade maranhense. Assim, a obra retrata valores e costumes familiares, aspectos históricos, arquitetônicos, políticos, culturais e sociais, sem deixar de lado a crítica social.

No último conto, por exemplo, utiliza a degradação dos Mirantes de São Luís como grande alegoria para criticar a decrepitude social: "Quantas páginas lancinantes e quantas alegrias exuberantes, como as que produzem a fortuna e o dinheiro dormem silenciosamente na mudez das suas pedras e dos seus telhados." ${ }^{44}$ (MORAES, 1982: 328).

\subsubsection{Neurose do Medo e 100 Artigos}

Essa obra está esgotada e talvez seja a mais difícil de ser encontrada, pois não há exemplares em bibliotecas ou sebos maranhenses e a sequência de artigos não está digitalizada exatamente em ordem.

Só tivemos contato com ela recentemente e trata-se de uma organização feita a partir dos artigos publicados por Nascimento Moraes durante sua carreira jornalística. Nessa edição, a primeira parte, que seria a referente ao livro Neurose do Medo, em que o autor critica social e politicamente o governo de Raul Machado (com Benedito Leite, foram os mais criticados pelo autor), que substituiu o governador Urbano Santos, na época ainda recebendo o título de presidente e foi deposto pelo Corpo Militar do Estado. ${ }^{45}$

Segundo o enunciador, por força pública, Raul Machado recusou-se a abdicar e ficou detido no Palácio do Governador. Foi levado à prisão domiciliar e houve a intervenção do exército e do governo federal, bem como os embates entre os apoiadores de

44 Moraes, José do Nascimento. Contos de Valério Santiago. São Luis: Secma, 1982, 328p. Tivemos contato com a obra recentemente; também é intensa a presença do discurso da negritude em sua composição enunciativa. Nela encontramos características íntimas da sociedade maranhense e da posição do negro naquela época.

$45 \quad$ O período republicano se inicia no Maranhão em 1889 com a Junta Governativa Maranhense. $O$ estado teve 63 governadores até a atualidade. Raul Machado foi governador em dois períodos:

em 1918 de 09 a 21 de outubro, quando foi deposto, neste período seu antecessor foi José Joaquim Marques e seu predecessor Urbano Santos da Costa Araújo;

em 20 de fevereiro de 1922 retoma o poder e governa até 20 de janeiro de 1923, quando por precedido por Godofredo Mendes Viana. 
Machado e os militares e seus opositores. De certo modo, o título "neurose do medo" faz referência às atitudes descabidas do governador, que deixara de confiar na maior parte de seus correligionários e da sociedade, após reassumir o poder e passara a viver com medo constante. Ele reagiu ao próprio medo, a ponto de contratar mercenários, afirmando que "não resta dúvida é que o medo presidencial era, sempre, cada vez mais crescente, correndo parelhas com ele os mais tenebrosos e selvagens planos de vingança, que a covardia alicerçava com um carinhoso egoísmo”. (MORAES, 1982:81). Todavia, o medo foi confirmado pela insurreição militar que o depôs definitivamente.

O enunciado de narrativa jornalística se desenvolve como um diário político seguido e transcrito por um jornalista. Embora não sejam datados, é possível acompanhar quase cinematograficamente o governo de Machado e suas reações diante da deposição, os vínculos de amizade e os posicionamentos políticos da situação e da oposição. Sobre Raul Machado diz:

[O sr. Raul Machado revelou-se um político dessa condenada escola que prejudica o nível moral das classes. Homem instruído, professor, jornalista, jurisperito, inteligente e educado, o sr. Raul Machado não manifesta em suas ações essa superior norma de homem público que traduz a excelência de uma cultura. Seus conhecimentos não the deram um ideal, não the esboçaram uma construção politica, não the assinalaram um alvo a atingir, um objetivo a colimar, uma aspiração a realizar, assim como um sonho de grandeza, muito rútilo, dentro do qual

se lhe afigurasse a coletividade.] (MORAES, 1982:55) [Era ele, o sr. Raul Machado, uma esperança. Representava uma garantia para a população descontentada? Não! O sr. Raul Machado sempre em público se manifestara de pleno acordo com a orientação política e administrativa do estadista maranhense! Sempre, em público, se revelara amigo incondicional do sr. Urbano Santos!] (MORAES,1982:61) [A mentira administrativa era um fato que ninguém podia contestar, e o sr. Raul Machado se mostrava solidário com essa mentira. A mentira administrativa gritava escandalosamente por todos os cantos e o sr. Raul Machado não se escusava de apoia-la!]

(MORAES,1982:61)

[Se o espírito do sr.Raul Machado tivesse tão combalido teria visto nessa ocasião que o seu governo não tinha as simpatias do povo, que p seu partido não tinha prestígio, nem força. ] (MO-

RAES, 1982:85)

Aplicando novamente o quadro adaptado de Maingueneau (2008), somente à primeira parte dessa obra, dentro dos limites possíveis para uma ilustração explicativa de uma tese, temos: 
Quadro XIX-Análise ilustrativa de Neuroses do Medo

\begin{tabular}{|c|c|c|}
\hline & Situação de enunciação & Situação de locução \\
\hline $\begin{array}{l}\text { Plano do Enunciado } \\
\text { Elementar }\end{array}$ & $\begin{array}{l}\text { Enunciador/coenunciador } \\
\text { Não-pessoa } \\
\text { Constitui-se na voz do ci- } \\
\text { dadão opositor ao governo } \\
\text { enunciador que tem como } \\
\text { coenunciador os situacionis- } \\
\text { tas e a sociedade em geral }\end{array}$ & $\begin{array}{l}\text { Locutor/alocutário } \\
\text { Delocutor } \\
\text { O locutor é um jornalista insatisfei- } \\
\text { to do jornal O Diário; não há delo- } \\
\text { cução, o locutor busca a adesão do } \\
\text { público-leitor. } \\
\text { O delocutor é também o jornalista } \\
\text { que fala da ingovernabilidade de } \\
\text { Raul Machado e das ações milita- } \\
\text { res, proclamando também a insatis- } \\
\text { fação geral }\end{array}$ \\
\hline \multirow[b]{3}{*}{ Plano do Texto } & \multicolumn{2}{|l|}{ Situação de discurso } \\
\hline & $\begin{array}{l}\text { Ponto de vista externo } \\
\text { Constrói-se a partir da inter- } \\
\text { locução entre a conjuntura } \\
\text { política e a mídia }\end{array}$ & $\begin{array}{l}\text { Ponto de vista interno } \\
\text { Cena de enunciação: ocorre por } \\
\text { meio do discurso relatado que de- } \\
\text { monstra a deposição do governador } \\
\text { e atribui ao medo o papel de motor } \\
\text { das ações precipitadas de Raul Ma- } \\
\text { chado }\end{array}$ \\
\hline & $\begin{array}{l}\text { Situação de comunicação } \\
\text { Narrativa jornalística; crôni- } \\
\text { cas distribuídas numa su- } \\
\text { cessão de cenas com ritmo } \\
\text { cinematográfico para retratar } \\
\text { a insatisfação política cau- } \\
\text { sada pelo governo de Raul } \\
\text { Machado }\end{array}$ & $\begin{array}{l}\text { Cena englobante: } \\
\text { Deposição do governo; embate en- } \\
\text { tre militares e mercenários } \\
\text { Cena genérica: artigos e crônicas. } \\
\text { Cenografia: diário jornalístico, rela- } \\
\text { tando a insatisfação com relação ao } \\
\text { presidente Raul Machado. } \\
\text { Revolução social e as reações vio- } \\
\text { lentas causadas pelo medo de per- } \\
\text { der o poder, por parte de Raul Ma- } \\
\text { chado. }\end{array}$ \\
\hline
\end{tabular}


A segunda parte da obra é composta por cenas genéricas ${ }^{46}$, em forma de artigos e crônicas escritos e publicados em diferentes épocas, nos jornais Tribuna e Diário Oficial, separados pelos seguintes universos discursivos: políticos, filosóficos, sociológicos e históricos; educacionais e literários (análise crítica). ${ }^{47}$

\subsubsection{Vencidos e Degenerados ${ }^{48}$}

Nesta seção, apresentamos Vencidos e Degenerados no que concerne à sua materialização textual, como gênero do discurso literário, para procedermos à análise discursiva, no último capítulo deste livro, dedicado à análise específica do corpus.

Ressaltamos que, também em seu discurso literário, o escritor imprimiu um tom jornalístico; e abordou de maneira crítica a temática do preconceito racial. Seu único romance, Vencidos e Degenerados, corpus específico deste livro, primeiramente publicado no Maranhão em 1915, demorou dois anos para ser editado ${ }^{49}$. Segundo os depoimentos iniciais na apresentação da quarta edição do livro, foi escrito "no sobrado do mirante sito na Rua da Cruz, então sob o n⿳0 61, esquina com a da Paz"50. Faremos um breve resumo da obra, uma vez que dedicaremos um capítulo inteiro à análise.

Vencidos e Degenerados é uma produção ainda pouco explorada no âmbito das pesquisas linguísticas e literárias, mas razoavelmente investigada, principalmente em pesquisas da área de História e Sociologia sobre a república maranhense e a sociedade abolicionista no Maranhão em diferentes universidades do País.

No prefácio escrito por Nauro Machado, ${ }^{51}$ para a obra Neuroses do Medo e 100 Artigos, há um ensaio sobre toda a obra de Moraes, que é assumido como

$46 \quad$ Cena genérica está relacionada ao gênero, conforme veremos nos Capítulos III e IV.

47 Esta obra cerca-se seguramente de aspectos pertencentes ao discurso da negritude, contudo, nosso envolvimento com seus textos é ainda recente e não fizemos uma pré-análise aplicativa, como já fizemos com Puxos e Repuxos, o quadro é somente aplicativo, pensando numa análise extensa futura.

48 Diferentemente das outras obras citadas, a análise propriamente dita de Vencidos e Degenerados será feita no capítulo VI. Aqui nos limitamos à apresentação do corpus, necessária ao conhecimento geral da obra para o primeiro contato. Essas características serão retomadas na apresentação das categorias de análise necessárias ao estudo da paratopia e demais aspectos da AD.

49 Essa edição é antecedida por depoimentos de contemporâneos de José do Nascimento Moraes. Humberto Ramos de Almeida Jansen Ferreira relata, no segundo depoimento de abertura, na apresentação inicial dessa edição que tem em suas memórias pueris ter ajudado a dobrar os cadernos, o livro demorou dois anos para ser editado, em razão da falta de recursos.

$50 \quad$ No primeiro depoimento, no livro, emitido por L. Porciúncula de Moraes.

51 Autor maranhense, nascido em São Luís, em 1935, considerado possuidor de "Vasto conhecimento de filosofia e arte em geral, em especial em literatura e cinema, o poeta domina a língua francesa desde a tenra idade. Escritor profissional, sem dúvida um clássico de Língua Portuguesa, no melhor e mais amplo sentido do particular para o universal, Nauro Machado vem, ao longo de 45 anos, construindo uma obra poética monumental no panorama da Literatura Brasileira e Portuguesa, representada já por trinta e quatro títulos". (Disponível em: <http://www.guesaerrante.com.br/2005/11/30/ Pagina356.htm>. Acesso em: 25 mar. 2015). 
"paradigmaticamente" filho do povo. "Fruto do desconcerto social, em seus desníveis gritantes, e não das preocupações metafísicas, em suas angustias hamletianas" (MACHADO,1982:11).

Mérian (apud MACHADO, 1982) ${ }^{52}$ afirma que se trata de um romance marcante que, certamente, torna-se estruturalmente uma crônica do Maranhão, verdadeiro documento sociológico, mas também histórico e político.

A encenação inicia-se em 13 de maio de 1888. Narrada em terceira pessoa, descreve a São Luís dos sobradões em torno das Ruas do Giz, Estrela, Trapiche e da Palma, e nas localidades centrais, hoje históricas, onde se localizavam os jornais. Seu protagonista principal é o negro na sociedade maranhense republicana pós Lei Áurea. O livro é dividido em duas partes: a primeira vai da abolição ao início do processo republicano e apresenta, de forma tênue, a infância do personagem principal, Cláudio; a segunda parte dedica-se à fase adulta de Cláudio e analisa a sociedade após a República.

Na primeira parte do livro, a personagem primária ${ }^{53}$ de destaque é José Olivier, por sua força e presença na narrativa, na análise discursiva, que procederemos no último capítulo. É considerado um enunciador importante por ser representante do discurso da negritude. Alguns leitores e críticos locais o consideram protagonista, entretanto, é pai adotivo de Cláudio e está na primeira parte somente para compor o espaço social em que Cláudio fora educado.

Olivier é jornalista, descrito como "vibrante e orador fluente que pela imprensa muito trabalhava em favor dos oprimidos", fisicamente

era um rapaz alto, magro, moreno, rosto largo, olhos negros e vivos, faiscando através das lentes do pince-nez. Envergava um fato azul-claro; trazia um colarinho alto, gravata parda, a borboletear. Não dispensava uma flor qualquer à botoeira, e exibia naquela manhã um desabrochado botão de rosa amarela, luvas no bolso do peito do paletó, e um palhinha airoso e leve. Caminhava com o passo largo e medido. Quando andava, metia o dedo no polegar na cava do colete, balançava o corpo e a cabeça, jogando com as espáduas, para a direita e para a esquerda, fronte alevantada, altiva, e se porventura a baixava era para se espalhar no verniz da botinha. Era mestiço e fora com dificuldade que se colocara na imprensa e se fizera guarda-livros de im-

52 Jean-Yves Mérian é estudioso da obra de Aluisio Azevedo, principalmente de $\mathrm{O} M u$ lato. Não encontramos o texto original ao qual Nauro Machado faz referência, ainda que essa análise seja reproduzida em alguns sites maranhenses, mas julgamos relevante expor seu comentário, considerando a referência válida pela seriedade imposta a Nauro Machado.

53 Dentro do estudo dos componentes da narrativa, há a divisão entre personagens protagonistas e antagonistas, e ambos dividem-se, em graus de envolvimento com o enredo, em primárias e secundárias, sendo essas últimas apenas suportes na composição da cena. 
portante casa comercial. Era um cronista excelente e sustentava no jornal as graças e as louçanias do dizer castiço e vernáculo.

(MORAES, 2000:28)

Olivier era membro do Clube Artístico Abolicionista Maranhense. Naquele momento, todos os componentes do clube dirigiam-se à casa de José Maria Maranhense, que também era

mulato, mais baixo que alto e careca. Contava quarenta e tantos anos, grisalho, gordo e simpático. Marceneiro de profissão e estudante nas horas vagas. Tinha decidido gosto pelas letras, pela ciência, por tudo, enfim, que fosse do domínio da inteligência humana. (MORAES, 2000:32)

Para aguardar a confirmação da assinatura da Lei Áurea por telégrafo, reuniu em sua casa os participantes do clube, amigos e vizinhos.

Em torno dessa espera e da reunião em casa de maranhense, o narrador descreve o clima de euforia da cidade em detalhes, bem como a situação de portugueses, escravos e ex-escravos, senhores, latifundiários e feitores. Descreve minudentemente a constituição econômica social; afirma que as relações trabalhistas estavam alteradas e que ainda havia uma maioria explorada. Além disso, denuncia senhores que se recusavam a aceitar as novas relações; escravos libertos que viviam em penúria; e outros que poupavam para ter seus próprios escravos e vestir-se como patrões.

Contudo, há os que trabalham por necessidade, os que são arrimos de seus pais, pelo menos os ajudam a viver, pobrezinhos, sem o alinhavo o do confortável e do cômodo. Conhece-se, à primeira vista, pela fisionomia e pelo trajo, pelo andar e pelos modos, nem se unem eles com os mais, para que se não sintam frequentemente humilhados no seu estado precário. São estes os futuros guarda-livros, os empregados de escritórios, os gerentes das grandes casas comerciais, porque enquanto aqueles, deixando o serviço em que sedistra em, correm aos folguedos, aos namoros e aos bailes, eles, os pobres e sacrificados que trabatham por necessidade, procuram habilitar-se nas aulas noturnas, onde estudam as matérias que são precisas para thes preparar o espirito para os mais importantes postos de sua profissão. Os que trabalham por vaidade pertencem, na sua maioria, às antigas famílias do Estado, ou às que delas descendem. Os necessitados são, na maior parte, oriundos do povo, pertencem às famílias pobres e desprotegidas que não se misturam com as que representam a fina flor da sociedade. Os que trabalham por fortuidade são, como os portugueses, mandados buscar nas vilas de 
Portugal, os futuros patrões, os diretores de Banco, os proprietários e capitalistas. (MORAES, 2000: 57)

Olivier é pai adotivo de Cláudio e esmerava-se em sua educação; seus pais legítimos eram Domingos Daniel Aranha e Andreza. Domingos Daniel Aranha era sapateiro e trabalhava e morava com Olimpio Santos. Porém, antes disso, tinha sido "capanga de seu senhor", capoeirista, era conhecido em toda São Luís por suas bravatas,

era mulato alto de meia idade, mais magro que gordo, pouca barba, bigode ralo, cabelos crespos. Trajava calça e camisa branca, cujas mangas arregaçava, chapéu de palha ordinária, mole, e não calçava. Era uma fisionomia simpática e essa simpatia lhe vinha do olhar claro e cheio de bondade. (MORAES, 2000:41)

Seu único amigo era Olímpio Santos, descrito como

um preto retinto, alto magro, rosto redondo, de expressão carregada de tédio, cabeça seca, olhos grandes e amortecidos. Dava-se-lhe, aproximadamente, trinta e poucos anos de idade. Trajava habitualmente fraque e colete preto, camisa branca, lustrosa, gravata preta, calça branca, dura de goma, chapéu de feltro, de copa alta, sapatos de pelica preta, de bom feitio. (MORAES,

2000:39)

Era de origem mina, mas era sozinho desde muito cedo, porque sua tia e sua mãe faleceram e nunca se casou. Ambos estavam em meio aos festejos do 13 de maio e são personagens que fazem parte de toda a narrativa do romance, do começo ao fim.

Andreza Vital também faz parte de toda a narrativa e está a caminho para as comemorações. Ela "era uma das satisfeitas, pois que se libertara em torno da Lei" (MORAES, 2000:47).

Era uma mulata alta, magra, simpática, de trinta e cinco a quarenta anos aproximadamente. Amasiara-se com o Aranha havia anos, muito antes do ano em que ele tivera de acompanhar o senhor pelas fazendas alheias, em conquistas amorosas. (MO-

RAES, 2000:47)

Mas separaram-se por mágoas do passado e, agora, ela expunha sua exuberância em festas e bares; havia rumores de que teria muitos amantes, embora seja descrita como séria e comedida. Ela dividia o que ganhava com a família de Olivier, que criava seu filho, e Aranha passava todos os dias para ver o filho e presentear a senhora que $o$ criava. Tomada por uma tristeza profunda, vivia envolvida em bebedeiras e pândegas.

Além desses personagens, há muitos outros secundários, de ordem menor, ex- 
ceto Zé Catraia e o quitandeiro/bodegueiro João Machado.

Zé Catraia era o bêbado mais conhecido da cidade, representava seus ouvidos, tudo sabia, até os mais íntimos segredos. Entrava nas festas burguesas sem ser convidado e vivia caído, dormindo pelas ruas de São Luís, quando lhe convinha, contava antigas histórias com as quais tinha contato, "tinha alguma coisa de orador popular" (MORAES, 2000:45). Libertou-se com a abolição da escravidão, mas a liberdade "não lhe trouxera propriamente vantagem que mereça menção. Era escravo de confiança de seu senhor, um velho decrépito que mais medo havia dele que ao diabo" (MORAES, 2000:46).

João Machado (apelidado Paletó Queimado) representa o desenvolvimento social e a ascensão comercial do português em terras maranhenses; mudou seu status $q u o$, pois enriquecera de forma ludibriosa e ampliara suas relações com o governo e com a burguesia. Após a República, torna-se o melhor amigo de Olivier, aproximando-se dele para adquirir o prestígio social dado aos homens endinheirados que tinham algo de saber.

Olivier tem um preceptor, o professor Carlos Bento Pereira, que critica abertamente a ordem social; organiza saraus literários; e sonha publicar um panfleto (manifesto) para chamar a atenção das pessoas em geral sobre os problemas que se instauram. Seria uma síntese social e política, à espera de renovação social apoiada por Olivier.

Cláudio assume efetivamente seu papel de protagonista e começa a trabalhar também no jornalismo com as bênçãos de Bento e o apadrinhamento de Machado e, após a morte de seu pai adotivo Olivier, passa a frequentar ainda mais a sociedade. Sobre Olivier, sabe-se que morreu esperando a transformação que não chegara, que não havia publicado o tal panfleto e

sua vida passara por uma transformação extraordinária. João Olivier, seu pai de criação, o vibrante e inesquecível cronista maranhense morrera ao voltar de Belém, para onde fora, depois de alguns anos de ostracismo em sua terra. O grupo político contrário ao que ele pertencia galgou o governo definitivamente. Olivier aguentou os primeiros anos de perseguição. Dava-lhe o ordenado de guarda-livros, o qual, por causa das péssimas condições do comércio, fora reduzido para as despesas mais urgentes. A crônica não lhe rendia nada. A imprensa maranhense é servida por um grupo de rapazes que gratuitamente trabalham, contentando-se com o representa-la nos bailes, nas festas, nos banquetes e no teatro. (MORAES, 2000:97)

Surge uma elite postiça e os clubes abolicionistas são extintos. Cláudio funda um grêmio literário, chamado Gonçalves Dias, "como houvesse marasmo no Maranhão, 
dormindo as letras um sono condenador e tanta atividade" (MORAES, 2000:103). Essa associação patrocinava encontros literários para discussões críticas e criou um jornal denominado $O$ Campeão, o que causa alvoroço na elite jovem maranhense que se sentia incomodada com o sucesso de um grupo de jovens composto em sua maioria por mestiços e sujeitos sem tradição familiar aristocrática. O sustentáculo do grupo é o nome do pai adotivo de Cláudio e a proteção de Machado, bem como o apoio de alguns jornais como $O$ Diário. Cláudio ainda mantém contato com o professor Bento e com o poeta Neiva.

O novo ponto de encontro desses jovens boêmios é a casa de João da Moda. Lugar onde há discussões literárias e bebedeiras entre homens e mulheres de diferentes idades. Embora as mulheres ainda estejam ali somente para a diversão dos homens, João da Moda é apresentado

com seu ar de requintada afabilidade, em mangas de camisa, bebia e comia com valentia. Mestiço, mais gordo que magro, de costeletas e com duas formidáveis entradas na fronte, sua figura atraiu logo a atenção de Cláudio, que de pé ao lado do companheiro, que se mostrava tão acostumado naquela casa, não sabia julgar do que ante seus olhos se mostrava. - Príncipe dos vencidos da vida! - bradou com voz muda Onésimo Trancoso. - Por que tardaste, tu que és o diamante desta orgia de que nós somos modestos ministros? (MORAES, 2000:116)

A descrição de João da Moda coincide com a primeira visita de Cláudio Olivier à casa, em que a expressão "vencidos da vida" aparece pela primeira vez. Entretanto, esse grupo se autodenomina vencidos e degenerados, pela maneira como afronta a sociedade. Num primeiro momento, parece que Cláudio fica perplexo com as bacanais, mas, no desenrolar da trama, descobre-se que João da Moda era muito parecido com o tenente-coronel Magalhães, o que também pode ter gerado essa atitude. Nessa visita, Cláudio conhece Armênia Cruz, na verdade, Armênia Magalhães,

A cabeleira negra, como lhe chamavam os romancistas daquela orgia, mulher de trinta e tantos anos, já em decadência de forma, em declínio de exuberança, mas ainda formosa, ainda simpática, ainda infernalmente sedutora, pela distinção do porte, pela admirável disposição de linhas, harmonia de membros, o bem lançado dos braços e dos seios entumecidos, que naquela noite arfavam num corpete cor-de-rosa, a sobressaírem com a graça sedutora, tronco esbelto repousado em soberbas colunas que se desenhavam bela na saia de cambraia branca. (MO-

RAES, 2000:115)

Armênia era filha do tenente-coronel Magalhães, senhor de escravos dos mais 
cruéis, cuja fortuna entrou em decadência após a abolição e, com sua morte, a moça havia sido rejeitada por muitos homens. Após a morte da mãe, havia rumores de que teria muitos amantes que lhe faziam promessas jamais cumpridas. Para vingar-se da sociedade, seduz o rapaz, vivendo um caso de amor noites a fio em sua casa, sem saber que, na verdade, não era filho legítimo de Olivier.

Em meio a uma bebedeira, João da Moda revela que, na verdade, é filho de Andreza com o coronel Magalhães e fora concebido por um ato de violência do coronel que a tomou, aproveitando-se da ausência de Aranha. Quando nasceu, João foi imediatamente afastado da mãe, por isso, Andreza não o reconhece e o rejeita, provavelmente por essa semelhança. Cláudio também descobre que Aranha separou-se de sua mãe por imaginar que ela vivesse uma relação consentida com o coronel. Por ser um homem muito cruel, o fim do Magalhães foi trágico; havia sido assassinado e todos desconfiavam de Aranha. Cláudio não revela sua paternidade e tampouco aceita os laços consanguíneos, por isso, não volta a falar no assunto e diz ter se esquecido dessa conversa.

O romance entre Cláudio e Armênia, no entanto, chega aos ouvidos da alta sociedade, que já se sentia incomodada com seu sucesso intelectual e os homens se sentem ultrajados por um "mestiço pobre" se sentir no direito de ser amante de uma senhora da sociedade; até mesmo porque não tem condições de mantê-la. Ele é avisado por Bento e Machado que, inclusive, ameaçam retirar seu apoio e apadrinhamento e pressionam comerciantes para os quais o rapaz trabalhava como guarda-livros, se ele insistisse em manter essa postura. E usam a religião, a família e a decência para dissuadi-lo.

Cláudio, porém, segue com suas atividades profissionais e seu caso amoroso com êxito. Os aristocratas, então, criam uma emboscada para tentar matá-lo, no que fracassam, graças a Aranha, que, ao saber por Zé Catraia que o filho corria risco, começa a segui-lo e consegue salvá-lo com suas habilidades de capoeira, mas aconselha o filho de partir de São Luís.

Num primeiro momento, Cláudio insiste em ficar porque as senhoras que o criaram dependiam dele financeiramente. No entanto, após o ataque, parte para o Amazonas, onde terá uma carreira de sucesso. Seu pai fica encarregado de cuidar das senhoras e receber o dinheiro enviado pelo correio por Cláudio.

A narrativa se encerra com os festejos de 15 de novembro: Cláudio aparece como convidado, após sete anos de ausência, acompanhado de uma paraguaia; revê os amigos; descobre que João da Moda morrera após uma bebedeira; Armênia estava agora casada com um aristocrata; descobre que o panfleto de Bento, autêntico manifesto dos direitos da população, nunca chegou a ser publicado. "Era um mundo novo a revelar-se, mas uma revelação sem ordem, toda fragmentada; era um ir e vir sobre os fatos" (MORAES, 2000:293).

Cláudio termina sentado, cheio de reminiscências de uma sociedade que já não 
mais existia. "Seu espírito fez uma viagem ao passado, e lá de suas brumas surgiu o vulto de João Olivier, que lhe repetiu essa frase: 'O panfleto do velho Bento é uma obra de Santa Engrácia”' (MORAES, 2000:296) e termina disfarçando lágrimas.

Neste capítulo, fizemos um percurso pela vida e obra de José do Nascimento Moraes, com sua relevante inserção na Literatura afro-brasileira, apresentando-as como no (Quadro X )

\section{Quadro X. - Vida e obra de José do Nascimento Moraes}

\begin{tabular}{|l|l|}
\hline \multicolumn{1}{|c|}{ Obras } & \multicolumn{1}{|c|}{ Apresentação } \\
\hline Puxos e Repuxos & $\begin{array}{l}\text { A partir da análise das colunas Fluxos e Re- } \\
\text { fluxos que deram origem à obra, apresen- } \\
\text { tamos o pseudônimo Valério Santiago com } \\
\text { o qual Nascimento Moraes atacava Antônio } \\
\text { Lobo (D. Galiza) e seu grupo para demons- } \\
\text { trar o discurso racista de Lobo e da resis- } \\
\text { tência pertinente ao discurso da negritude } \\
\text { de Valério Santiago. Para isso, utilizamos } \\
\text { os princípios de Charaudeau (2006) no que } \\
\text { concerne ao discurso jornalístico e Maingue- } \\
\text { neau (2008) no que se refere ao plano de } \\
\text { enunciação } \\
\text { Após essa análise, apresentamos a compo- } \\
\text { sição da obra Contos de Valério Santiago, } \\
\text { que denota outra vertente do mesmo enun- } \\
\text { ciador }\end{array}$ \\
\hline Neurose do Medo e 100 Arti- \\
gos & $\begin{array}{l}\text { Apresentamos a estrutura da obra dividida } \\
\text { em duas partes. A primeira é analisada no } \\
\text { plano enunciativo para demonstrar o ponto } \\
\text { de vista crítico do enunciador com relação a } \\
\text { aspectos políticos da sociedade maranhen- } \\
\text { se e, a segunda, por se tratar de um apanha- } \\
\text { do de crônicas e artigos jornalísticos, foram } \\
\text { feitos comentários delimitados ao espaço da } \\
\text { tese }\end{array}$ \\
\hline Vencidos e Degenerados & $\begin{array}{l}\text { Apresentamos a síntese do romance para } \\
\text { que seja retomada durante a apresentação } \\
\text { teórica e análise final sem perda de sentido }\end{array}$ \\
\hline apos
\end{tabular}

Após o reconhecimento dos dizeres múltiplos do(s) enunciador(es) de nosso corpus, resta enveredar pelas fronteiras discursivas até chegarmos à análise final. Com esta primeira explanação, estabelecemos um norte referencial para os exemplos e as ilustrações que serão feitos nos capítulos teóricos. 